University of Nebraska - Lincoln

DigitalCommons@University of Nebraska - Lincoln

\title{
Mineralogical transformations controlling acid mine drainage chemistry
}

\section{T. Peretyazhko}

Pacific Northwest National Laboratory, tetyana.peretyazhko@pnl.gov

John M. Zachara

Pacific Northwest National Laboratory, john.zachara@pnl.gov

J.-F. Boily

Pacific Northwest National Laboratory

Y. Xia

Pacific Northwest National Laboratory

P.L. Gassman

Pacific Northwest National Laboratory

See next page for additional authors

Follow this and additional works at: https://digitalcommons.unl.edu/usdoepub

Part of the Bioresource and Agricultural Engineering Commons

Peretyazhko, T.; Zachara, John M.; Boily, J.-F.; Xia, Y.; Gassman, P.L.; Arey, B.W.; and Burgos, W.D., "Mineralogical transformations controlling acid mine drainage chemistry" (2009). US Department of Energy Publications. 194.

https://digitalcommons.unl.edu/usdoepub/194

This Article is brought to you for free and open access by the U.S. Department of Energy at DigitalCommons@University of Nebraska - Lincoln. It has been accepted for inclusion in US Department of Energy Publications by an authorized administrator of DigitalCommons@University of Nebraska - Lincoln. 


\section{Authors}

T. Peretyazhko, John M. Zachara, J.-F. Boily, Y. Xia, P.L. Gassman, B.W. Arey, and W.D. Burgos 


\title{
Mineralogical transformations controlling acid mine drainage chemistry
}

\author{
T. Peretyazhko a,*, J.M. Zachara ${ }^{\text {a }}$, J.-F. Boily ${ }^{\text {a }}$, Y. Xia ${ }^{\text {a }}$, P.L. Gassman ${ }^{\text {a }}$, B.W. Arey ${ }^{\text {a }}$, W.D. Burgos ${ }^{\text {b }}$ \\ a Pacific Northwest National Laboratory, Richland, WA 99354, United States \\ b Department of Civil and Environmental Engineering, The Pennsylvania State University, PA, 16802, United States
}

\section{A R T I C L E I N F O}

\section{Article history:}

Received 10 September 2008

Received in revised form 16 January 2009

Accepted 19 January 2009

Editor: J. Fein

\section{Keywords:}

Acid mine drainage

Schwertmannite

Mineralogical transformations

\begin{abstract}
A B S T R A C T
The role of Fe(III) minerals in controlling acid mine drainage (AMD) chemistry was studied using samples from two AMD sites [Gum Boot (GB) and Fridays-2 (FR)] located in northern Pennsylvania. Chemical extractions, X-ray diffraction (XRD), scanning electron microscopy (SEM), and Fourier transform infrared spectroscopy (FTIR) were used to identify and characterize Fe(III) phases. The mineralogical analysis revealed schwertmannite and goethite as the principal Fe(III) phases in the sediments. Schwertmannite particles occurred as sub-micron sized spheroids. Their transformation into goethite occurred at the GB site where poorly-crystallized goethite rich in surface-bound sulfate was initially formed. In contrast, no schwertmannite transformation occurred at the FR site. The resulting goethite in GB sediments was also of spherical morphology and resulted from an in situ phase transformation involving the conversion of bulkbound schwertmannite sulfate ions into goethite surface complexes. Chemical extractions moreover showed that the poorly-crystallized goethite particles were subject to further crystallization accompanied by sulfate desorption. Changes in sulfate speciation preceded its desorption, with a conversion of bidentate- to monodentate-bound sulfate surface complexes.

Laboratory sediment incubation experiments were conducted to evaluate the effect of mineral transformation on water chemistry. Incubation experiments were carried out with schwertmannite-containing sediments and aerobic AMD waters with different $\mathrm{pH}$ and chemical composition. The $\mathrm{pH}$ decreased to 1.9-2.2 in all suspensions and the concentrations of dissolved Fe and S increased significantly. Regardless of differences in the initial water composition, $\mathrm{pH}$, Fe and $\mathrm{S}$ were similar in suspensions of the same sediment. XRD measurements revealed that schwertmannite transformed into goethite in GB and FR sediments during laboratory incubation. The incubation experiments demonstrated that schwertmannite transformation controlled AMD water chemistry under no-flow, batch conditions.
\end{abstract}

(c) 2009 Elsevier B.V. All rights reserved.

\section{Introduction}

Acid mine drainage (AMD) is produced by biotic and abiotic oxidation of sulfide minerals (ex., pyrite, $\mathrm{FeS}_{2}$ ), and the subsequent release of large amounts iron and sulfuric acid $\left(\mathrm{H}_{2} \mathrm{SO}_{4}\right)$ to aqueous systems (Bigham et al., 1996; Malmstrom et al., 2006; Cravotta, 2008). Contamination of natural waters with AMD leads to severe acidification and release of toxic elements from mining residues; and induces the erosion, sedimentation and precipitation of Fe(III) minerals (Bigham and Nordstrom, 2000). The extent of damage depends on different controlling factors including the size and buffering capacity of the receiving stream as well as the biogeochemical properties of the AMD (Bigham and Nordstrom, 2000). The physico-chemical, microbiological, and mineralogical processes involved in AMD must therefore be thoroughly understood to evaluate and mitigate their impacts to the environment.

\footnotetext{
* Corresponding author. Pacific Northwest National Laboratory, PO Box 999, MS K8-96 Richland, WA 99354, United States. Tel.: +1 509376 1529; fax: +1 5093763650.

E-mail address: tetyana.peretyazhko@pnl.gov (T. Peretyazhko).
}

Iron(III) precipitates play a determining role in AMD water quality (Sullivan and Bush, 2004; Acero et al., 2006). For example, the type of $\mathrm{Fe}(\mathrm{III})$ mineral formed determines the amount of acidity developed (Dold and Fontbote, 2001). Iron(III) minerals usually found in AMD include jarosite $\left[\mathrm{KFe}_{3}\left(\mathrm{SO}_{4}\right)_{2}(\mathrm{OH})_{6}\right]$, goethite $[\alpha-\mathrm{FeOOH}]$, ferrihydrite $\left[\mathrm{Fe}_{5} \mathrm{OH}_{8} \cdot 4 \mathrm{H}_{2} \mathrm{O}\right]$ and schwertmannite $\left[\mathrm{Fe}_{8} \mathrm{O}_{8}(\mathrm{OH})_{8-2 x}\left(\mathrm{SO}_{4}\right)_{x} \cdot \mathrm{nH}_{2} \mathrm{O}\right.$ where $1 \leq x \leq 1.75$ ] (Schwertmann et al., 1995; Bigham et al., 1996; Hochella et al., 1999; Gagliano et al., 2004; Murad and Rojik, 2005). Jarosite forms at $\mathrm{pH}<3$ and high sulfate concentrations, while ferrihydrite and goethite precipitate at circumneutral $\mathrm{pH}$ (Schwertmann and Carlson, 2005). Schwertmannite, on the other hand, is a most common phase precipitating between $\mathrm{pH} 3$ and 4 (Bigham et al., 1996). Schwertmannite acts as an important sink for minor elements (e.g., As, $\mathrm{Hg}, \mathrm{Pb}, \mathrm{Cr}$ ) through adsorption or coprecipitation reactions (Bigham and Nordstrom, 2000; Carlson et al., 2002; Fukushi et al., 2003; Regenspurg and Peiffer, 2005; Espana et al., 2006). It can also undergo hydrolysis reactions and consequently be responsible for acidity increase in aqueous environments (Dold and Fontbote, 2001; Sullivan and Bush, 2004). 
Numerous studies demonstrate that goethite is often present in AMD precipitates dominated by schwertmannite (Bigham et al., 1996; Gagliano et al., 2004; Murad and Rojik, 2005; Schwertmann and Carlson, 2005). Schwertmannite is apparently metastable with respect to goethite, and transforms to this more stable phase by hydrolysis within months to years (Bigham et al., 1996; Gagliano et al., 2004; Murad and Rojik, 2005; Schwertmann and Carlson, 2005) through the reaction:

$\mathrm{Fe}_{8} \mathrm{O}_{8}(\mathrm{OH})_{5.5}\left(\mathrm{SO}_{4}\right)_{1.25}+2.5 \mathrm{H}_{2} \mathrm{O} \rightarrow 8 \mathrm{FeOOH}+2.5 \mathrm{H}^{+}+1.25 \mathrm{SO}_{4}^{2-}$

Limited evidence suggests that rate of transformation depends on solution physico-chemical properties, increasing with $\mathrm{pH}$ and temperature (Jönsson et al., 2005; Schwertmann and Carlson, 2005), and decreasing with increasing concentrations of sulfate and dissolved organic carbon (Knorr and Blodau, 2007). Recent research has shown that schwertmannite transformation also occurred under anoxic conditions and $\mathrm{Fe}$ (II)-catalyzed conversion of schwertmannite to goethite is very rapid (Burton et al., 2008).

In this communication we compare the mineralogy of two sites [Gum Boot(GB) and Fridays-2 (FR)] that exhibit comparable source AMD discharge compositions, but variable rates of downstream oxygenation, microbiological $\mathrm{Fe}(\mathrm{II})$ oxidation, and Fe precipitation rates as described by Senko et al. (2008). A primary goal was to investigate whether relationships existed between the current phase distribution, mineralogic transformation products, and the downstream water composition of the AMD that was different between sites. For this purpose we characterized the morphology, mineralogy, and chemical composition of AMD precipitates with distance from the source terms, and with accumulation depth, using chemical extractions, X-ray diffraction (XRD), and scanning electron microscopy (SEM) with elemental analysis. Additionally, the bulk and surface speciation of sulfate was determined on field-derived AMD precipitates using Fourier-transform infrared spectroscopy (FTIR), with multi-component asynchronous correlation analysis. Laboratory batch incubation experiments were performed with schwertmannite-containing GB and FR sediments and AMD waters of different composition to investigate temporal relationships between water chemistry and AMD mineralogy. We demonstrate that mineralogic transformations of initial AMD precipitates are more closely associated with the evolving surface speciation of sulfate, rather than through the catalytic action of Fe(II).

\section{Materials and methods}

\subsection{Field site and sampling}

Two AMD sites were chosen for this study (Senko et al., 2008). The Gum Boot (GB) system is located in McKean County, Pennsylvania $\left(41^{\circ} 41^{\prime} 02^{\prime \prime} \mathrm{N} ; 78^{\circ} 29^{\prime} 37^{\prime \prime} \mathrm{W}\right.$ ), and the Fridays-2 (FR) system is located in Clearfield County, Pennsylvania ( $41^{\circ} 14^{\prime} 34^{\prime \prime} \mathrm{N} ; 78^{\circ} 32^{\prime} 28^{\prime \prime} \mathrm{W}$ ). At the GB site, AMD emerges at the crest of a hill and flows approximately $18 \mathrm{~m}$ downhill in $5 \mathrm{~mm}$ sills before flowing underground, reemerging at a point approximately $48 \mathrm{~m}$ downhill from the source. Discharge waters enter a pool at the foot of the hill $127 \mathrm{~m}$ from the source that subsequently discharge into nearby Gum Boot Run. Water and surface sediment samples were collected in February and May 2006, at discrete sampling points at $0 \mathrm{~m}$ and downstream of the AMD emergence point 2, 9, 15, 60, and $127 \mathrm{~m}$ (labeled GB1-GB6). Sediment samples at multiple depths were collected in May 2006 at points 0, 2 and $9 \mathrm{~m}$.

AMD emerges at a former mine entrance at the FR site that flows in sheets (approximately $5 \mathrm{~mm}$ deep) approximately $10 \mathrm{~m}$ before entering an adjacent unnamed creek. Water and surface sediment samples were collected in February 2006 at discrete sampling points $0 \mathrm{~m}$ (the AMD source, FR1 ), 2, 8 and $10 \mathrm{~m}$ downstream from the AMD emergence point. Two additional surface samples were collected at both sites, GB1 and FR1, in July 2006; these samples were used in the incubation experiments (see Section 2.3, "Sediment incubation"). Surface sediments were collected from the top $2 \mathrm{~cm}$ of sediment into $50-\mathrm{ml}$ sterile centrifuge tubes. Sediment depth columns were collected using stainless steel split spoons that were driven into AMD sediment.

Table 1

Mineralogy of the GB and FR precipitates and concentrations of oxalate, $6 \mathrm{M} \mathrm{HCl}$ and pH 10 extracted Fe and S.

\begin{tabular}{|c|c|c|c|c|c|c|c|}
\hline Sample & Location, $\mathrm{m}$ & XRD & $\mathrm{Fe}_{\mathrm{ox}}$ & $\mathrm{Fe}_{\mathrm{HCl}}$ & $\mathrm{S}_{\mathrm{ox}} \mathrm{mmol} / \mathrm{g}$ & $\mathrm{S}_{\mathrm{HCl}}$ & $\mathrm{S}_{\mathrm{pH} 10}$ \\
\hline \multicolumn{8}{|c|}{ Surface sediments (collected in February 2006) } \\
\hline GB1 & 0 & gt & $6.41 \pm 0.21$ & $8.56 \pm 0.09$ & $1.00 \pm 0.02$ & $1.12 \pm 0.02$ & $0.97 \pm 0.02$ \\
\hline GB2 & 2 & gt & $7.91 \pm 0.28$ & $8.43 \pm 0.29$ & $1.26 \pm 0.02$ & $1.30 \pm 0.04$ & $1.04 \pm 0.02$ \\
\hline GB3 & 9 & gt & $5.62 \pm 0.33$ & $9.13 \pm 0.27$ & $0.65 \pm 0.02$ & $0.74 \pm 0.02$ & $0.57 \pm 0.01$ \\
\hline GB4 & 15 & gt & $5.23 \pm 0.14$ & $9.05 \pm 0.08$ & $0.62 \pm 0.01$ & $0.74 \pm 0.01$ & $0.55 \pm 0.01$ \\
\hline GB5 & 60 & gt, qz & $0.17 \pm 0.04$ & $7.81 \pm 0.19$ & $0.26 \pm 0.02$ & $0.51 \pm 0.01$ & $0.32 \pm 0.02$ \\
\hline GB6 & 127 & gt, qz & $0.18 \pm 0.03$ & $4.09 \pm 0.08$ & $0.08 \pm 0.01$ & $0.14 \pm 0.01$ & $0.08 \pm 0.01$ \\
\hline FR1 & 0 & $\mathrm{sh}$ & $7.28 \pm 0.13$ & $8.23 \pm 0.09$ & $1.30 \pm 0.00$ & $1.36 \pm 0.00$ & $1.20 \pm 0.01$ \\
\hline FR2 & 2 & $\mathrm{sh}$ & $6.51 \pm 0.06$ & $7.65 \pm 0.17$ & $1.19 \pm 0.00$ & $1.37 \pm 0.03$ & $0.92 \pm 0.02$ \\
\hline FR3 & 8 & sh & $6.76 \pm 0.72$ & $7.93 \pm 0.21$ & $1.27 \pm 0.05$ & $1.43 \pm 0.01$ & $0.85 \pm 0.01$ \\
\hline FR4 & 10 & sh, gt & $6.94 \pm 0.55$ & $7.36 \pm 0.15$ & $1.20 \pm 0.02$ & $1.37 \pm 0.03$ & $1.22 \pm 0.03$ \\
\hline \multicolumn{8}{|c|}{ Surface sediments (collected in July 2006)* } \\
\hline GB1 & 0 & sh, gt & $6.81 \pm 0.34$ & $7.20 \pm 0.29$ & $1.32 \pm 0.09$ & $1.42 \pm 0.06$ & $0.69 \pm 0.02$ \\
\hline FR1 & 0 & sh, gt & $6.68 \pm 0.16$ & $6.89 \pm 0.14$ & $1.40 \pm 0.13$ & $1.40 \pm 0.11$ & $0.83 \pm 0.04$ \\
\hline \multicolumn{8}{|c|}{ Vertical profiles (collected in May 2006) } \\
\hline GB1D & $0-0.15$ & sh, gt & $5.05 \pm 0.13$ & $8.15 \pm 0.18$ & $0.95 \pm 0.02$ & $1.03 \pm 0.00$ & $0.74 \pm 0.01$ \\
\hline GB1D & $0.15-0.3$ & sh, gt & $7.22 \pm 0.11$ & $8.34 \pm 0.12$ & $0.95 \pm 0.00$ & $1.07 \pm 0.00$ & $0.68 \pm 0.01$ \\
\hline GB1D & $0.35-0.55$ & gt, sh & $6.24 \pm 0.20$ & $8.56 \pm 0.25$ & $0.72 \pm 0.01$ & $0.81 \pm 0.01$ & $0.61 \pm 0.02$ \\
\hline GB1D & $0.6-0.8$ & gt & $5.17 \pm 0.23$ & $9.07 \pm 0.14$ & $0.52 \pm 0.01$ & $0.63 \pm 0.00$ & $0.57 \pm 0.01$ \\
\hline GB1D & $0.9-1.1$ & gt & $3.49 \pm 0.13$ & $9.53 \pm 0.22$ & $0.31 \pm 0.01$ & $0.42 \pm 0.01$ & $0.35 \pm 0.01$ \\
\hline GB2D & $0-0.15$ & sh & $7.26 \pm 0.41$ & $7.76 \pm 0.22$ & $1.18 \pm 0.03$ & $1.32 \pm 0.00$ & $0.79 \pm 0.02$ \\
\hline GB2D & $0.15-0.5$ & sh, gt & $7.69 \pm 0.37$ & $7.99 \pm 0.05$ & $1.12 \pm 0.01$ & $1.19 \pm 0.01$ & $0.77 \pm 0.01$ \\
\hline GB2D & $0.6-0.8$ & gt & $2.52 \pm 0.07$ & $9.01 \pm 0.12$ & $0.36 \pm 0.00$ & $0.46 \pm 0.03$ & $0.37 \pm 0.01$ \\
\hline GB3D & $0-0.15$ & gt & $2.27 \pm 0.06$ & $9.66 \pm 0.14$ & $0.40 \pm 0.01$ & $0.54 \pm 0.02$ & $0.41 \pm 0.01$ \\
\hline GB3D & $0.2-0.4$ & gt & $2.72 \pm 0.14$ & $9.27 \pm 0.21$ & $0.42 \pm 0.00$ & $0.51 \pm 0.00$ & $0.40 \pm 0.14$ \\
\hline GB3D & $0.4-0.6$ & gt & $2.80 \pm 0.11$ & $8.32 \pm 0.22$ & $0.37 \pm 0.01$ & $0.45 \pm 0.02$ & $0.40 \pm 0.01$ \\
\hline GB3D & $0.6-0.8$ & gt & $2.42 \pm 0.07$ & $8.64 \pm 0.45$ & $0.37 \pm 0.00$ & $0.45 \pm 0.01$ & $0.41 \pm 0.01$ \\
\hline
\end{tabular}

*Used in incubation experiments. gt-goethite, sh-schwertmannite and qz-quartz. 


\subsection{Sediment characterization}

\subsubsection{Extractions and XRD analyzes}

Sediments samples were air-dried and sieved $(<2 \mathrm{~mm})$ prior to characterization and incubation.

Ammonium oxalate extraction in the absence of light was performed on each AMD sediment (Bigham et al., 1990; Gagliano et al., 2004; Regenspurg et al., 2004). A 50 mg sediment sample (six replicates) was mixed with ammonium oxalate reagent $(28 \mathrm{~g} / \mathrm{L}$ ammonium oxalate $+15 \mathrm{~g} / \mathrm{L}$ oxalic acid solution, $\mathrm{pH} \sim 2.7$ ). Samples were shaken in the dark for $4 \mathrm{~h}$, then centrifuged ( $3000 \mathrm{rpm}, 10 \mathrm{~min}$ ) and filtered $(<0.22 \mu \mathrm{m})$. This extraction dissolves poorly-crystalline $\mathrm{Fe}$ (III) oxides (ferrihydrite, schwertmannite) in presence of more insoluble crystalline Fe (III) oxides (goethite, hematite) (Cornell and Schwertmann, 2003). Sulfate-rich AMD goethite of poor crystallinity can also be partially dissolved by acid ammonium oxalate (Kumpulainen et al., 2007).

The total dissolution of $\mathrm{Fe}(\mathrm{III})$ precipitates was performed using 6 M HCl (Gagliano et al., 2004; Regenspurg et al., 2004). A sediment sample of $50 \mathrm{mg}$ (six replicates) was added to $10 \mathrm{~mL} 6 \mathrm{M} \mathrm{HCl}$. Samples were shaken for $48 \mathrm{~h}$, then centrifuged and filtered.

Sediment extractions were carried out at $\mathrm{pH} 10$ to evaluate the amount of surface bound sulfate (Kawano and Tomita, 2001). The efficiency of this extraction was evaluated using two sediment samples [GB1 (July) and FR1 (July)] that were dominated by schwertmannite (Fig. S1). Approximately $50-60 \%$ of $\mathrm{S}_{\mathrm{HCl}}(\mathrm{HCl}-$ extractable sulfate) was extracted after $10 \mathrm{~min}$ [samples were mixed with pH 10 buffer $\left(\mathrm{NH}_{4} \mathrm{OH} / \mathrm{NH}_{4} \mathrm{Cl} ; 7 \% \mathrm{NH}_{4} \mathrm{OH}, 1 \% \mathrm{NH}_{4} \mathrm{Cl}, 92 \% \mathrm{H}_{2} \mathrm{O}\right)$ and immediately centrifuged for $10 \mathrm{~min}$ ], and up to $80 \%$ of $\mathrm{S}_{\mathrm{HCl}}$ was extracted after $24 \mathrm{~h}$ (Table. S1). X-ray diffraction measurements revealed no change after $10 \mathrm{~min}$ of $\mathrm{pH} 10$ extraction. The goethite 110 and 111 peaks, however, became more pronounced after $24 \mathrm{~h}$ extraction (Fig. S1). Therefore, a $10 \mathrm{~min}$ extraction was applied to estimate the amount of adsorbed sulfate in order to avoid any structural changes to AMD mineral phases. For the extraction, $100 \mathrm{mg}$

a

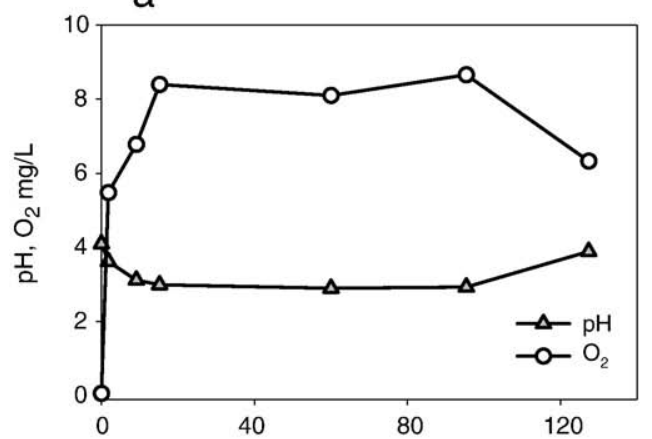

C

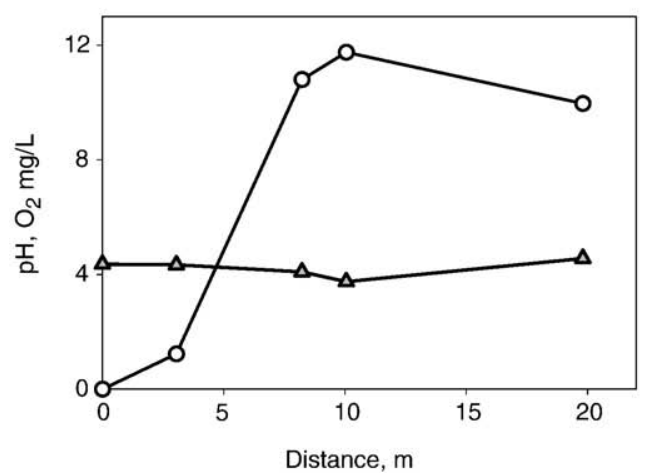

of sediment (six replicates) was added to $10 \mathrm{~mL}$ of $\mathrm{pH} 10$ buffer. The samples were well mixed, immediately centrifuged for $10 \mathrm{~min}$ at $3000 \mathrm{rpm}$, and filtered. The extracted solutions were analyzed for Fe and $\mathrm{S}$ by ICP-AES. We assumed that all S extracted from the sediment samples was present in the form of sulfate (hereafter denoted as $S$ ), as documented in other studies of AMD sediments (Jönsson et al., 2005).

Powder X-ray diffraction patterns of the sediments were recorded using a high-resolution $\Omega-2 \Theta$ Four-Circle X-ray Diffractometer (Philips X'Pert MRD PRO, Philips Co., Sunnyvale, CA). Intensities were measured with a $0.02^{\circ}$ step size and $2 \mathrm{~s}$ counting time per step.

\subsubsection{SEM}

Whole mount samples were prepared for SEM imaging by fixation to carbon tape. Air-dried sediments were also fixed with EpoThin epoxy (Buehler) to prepare thin sections. Samples were dried overnight, cemented to quartz optical grade microscope slides (25.4 $\mathrm{mm} \times 25.4 \mathrm{~mm} \times 1 \mathrm{~mm}$, SPI), sectioned [Isomet 1000 diamond blade thin sectioning saw (Buehler) with Isocut fluid] and polished [aluminum oxide sand paper, TEXMET 1000 (Buehler) and $1 \mu \mathrm{m}$ diamond polish (Metadi II , Buehler)]. Imaging and EDS analysis were performed using a LEO82 field emission SEM operating at $3 \mathrm{kV}$ fitted with backscattered and secondary electron detectors, coupled with an Oxford EDS system.

\subsubsection{FTIR}

The FTIR of the GB samples were collected as a function of distance from the AMD source (GB1, GB3, GB5) and as a function of depth (GB1D depth samples) using the $\mathrm{KBr}$ technique. The measurements were carried out on a Bruker IFS 66v/S FTIR spectrometer, equipped with a Globar source, KBr beam splitter, MCT detector and OPUS operating software. Each spectrum was derived from 512 co-added scans collected in transmission mode in the $2000-800 \mathrm{~cm}^{-1}$ range with a spectral resolution of $4 \mathrm{~cm}^{-1}$. All spectra were expanded to a Two-Dimensional Asynchronous correlation map (Noda and Ozaki, 2004) using the code of Boily and Ilton (2008). This map allowed identification of the precise
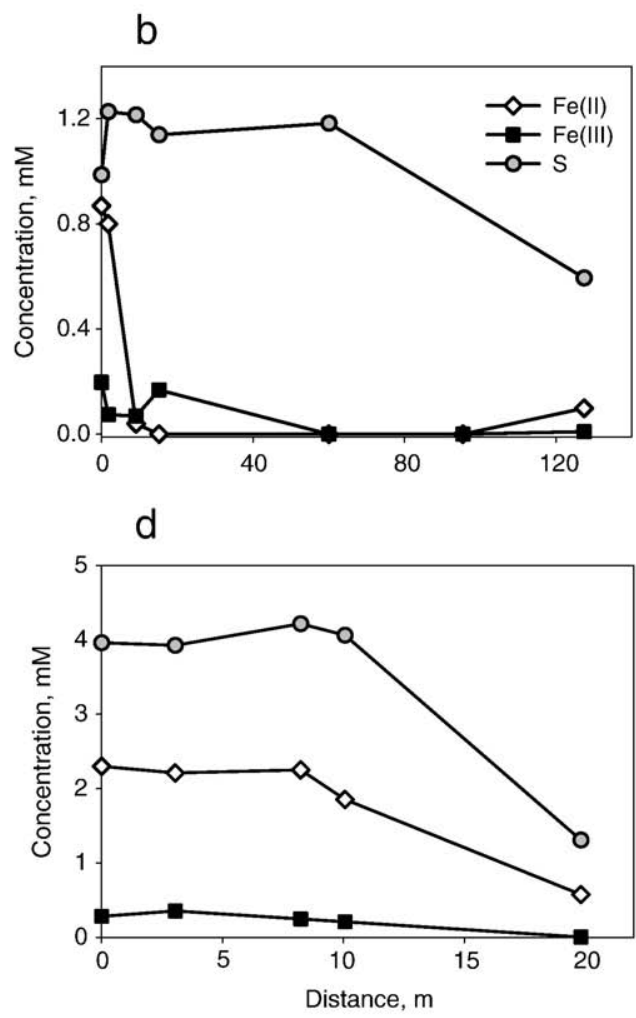

Fig. 1. Distributions of aquatic physico-chemical parameters as a function of distance from source: (a) and (b) GB; (c) and (d) FR. 
positions of the various $\mathrm{S}-\mathrm{O}$ stretching vibration bands of sulfate associated with various $\mathrm{Fe}(\mathrm{III})$ minerals. All calculations and mapping procedures were performed with Matlab (The Mathworks, Inc.).

The spectra were used to document changes in (1) the bulk and surface speciation of sulfate ( $\mathrm{S}-\mathrm{O}$ stretching vibrations) and (2) the mineralogical compositions as a function of distance and depth from the AMD source. Our interpretations are supported by the results of an unpublished study in which we followed the effects of $\mathrm{pH}$ and dehydration on the speciation of bulk and surface-bound sulfate ions in synthetic schwertmannite. Our study shows some changes caused by dehydration, mostly in the promotion of band splitting in circumneutral $\mathrm{pH}$ conditions compared to the wet state (Jönsson et al., 2005). The trends in the $\mathrm{pH}$ dependence of the spectra were however qualitatively similar to those of Jönsson et al. (2005) with three dominant forms of sulfate that will be further discussed in Section 3.2.3.

\subsection{Sediment incubation}

Incubation experiments (310 d) were performed to investigate transformations of metastable mineral phases in the sediment, and associated changes in AMD water chemistry. The $<2 \mathrm{~mm}$ size fraction of the air-dried GB1 (July) and FR1 (July) samples were used in two series of sediment incubations, one with GB4 water and another with GB6 water. The sediments contained mainly schwertmannite with traces of goethite by XRD (Fig. S1, Table 1), and displayed similar Fe and S contents (Table 1). The $\mathrm{N}_{2}$-BET specific surface areas were $190 \mathrm{~m}^{2} / \mathrm{g}$ (GB1) and $180 \mathrm{~m}^{2} / \mathrm{g}$ (FR1), with pore sizes of less than $20 \AA$. The two waters used for incubation had different compositions (Table. S1); GB4 was more acidic, and contained higher concentrations of $\mathrm{Fe}, \mathrm{S}$ and other elements.

Sediment suspensions were prepared by mixing $10 \mathrm{~g}$ of the sediments with $200 \mathrm{~mL}$ of AMD water in $250-\mathrm{mL}$ plastic bottles. Two replicates were prepared for each treatment [GB1 sediment + GB4 water (GB1s_GB4w), GB1 sediment + GB6 water (GB1s_GB6w), FR1 sediment + GB4 water (FR1s_GB4w), and FR1 sediment + GB6 water (FR1s_GB6w)]. pH was measured at selected time points, and suspension subsamples were collected and centrifuged $(3000 \mathrm{rpm}$, $10 \mathrm{~min}$ ) for phase separation. The resulting aqueous phase was analyzed for Fe and S by ICP-AES. The sediment samples were airdried, and then extracted with ammonium oxalate and $\mathrm{pH} 10$ buffer.

\subsection{Thermodynamic calculations}

Saturation indices were calculated for schwertmannite and goethite using PHREEQC [Version 2.14, (Parkhurst and Appelo, $1999)$ ]. The solubility product constants $\left(K_{\mathrm{sp}}\right)$ were taken from Bigham et al. (1996) for the two following reactions:

$$
\begin{aligned}
& \mathrm{Fe}_{8} \mathrm{O}_{8}(\mathrm{OH})_{x}\left(\mathrm{SO}_{4}\right)_{y}+(24-2 y) \mathrm{H}^{+}=8 \mathrm{Fe}^{3+}+y \mathrm{SO}_{4}^{2-}+(24-2 y+x) / 2 \mathrm{H}_{2} \mathrm{O} \\
& \quad \log K_{\mathrm{sp}}=18.0 \pm 2.5 \\
& \mathrm{FeOOH}+3 \mathrm{H}^{+}=\mathrm{Fe}^{3+}+2 \mathrm{H}_{2} \mathrm{O} ; \log K_{\mathrm{sp}}=1.4 \pm 0.01
\end{aligned}
$$

From Eqs. (2) and (3) and the solubility products, the following stability relationships were obtained

schwertmannite : $\mathrm{pa}_{\mathrm{Fe} 3+}=-2.82+2.6 \mathrm{pH}$

and

goethite : $\mathrm{pa} a_{\mathrm{Fe} 3+}=-1.4+3 \mathrm{pH}$

where $a_{\mathrm{Fe} 3+}=-\log a_{\mathrm{Fe} 3+}, a_{\mathrm{Fe} 3+}=$ the activity of $\mathrm{Fe}^{3+}$. Eq. (4) was fixed with an average $\mathrm{pa} a_{\mathrm{SO} 42-}=2.84 \pm 0.16$ [calculated based on dissolved $\mathrm{S}, \mathrm{Fe}$ and $\mathrm{pH}$ (Fig. 8) using PHREEQC], $x=4.8$ and $y=1.6$ [Eq. (2), Bigham et al., 1996]. Variation in $\mathrm{pa}_{\mathrm{SO} 42-}$ didn't result in significant changes in the calculated $\mathrm{pa}_{\mathrm{Fe} 3+}$, therefore, the solubility line of schwertmannite was calculated only with the average $\mathrm{p} a_{\mathrm{SO} 42-}=2.84$.

\section{Results and discussion}

\subsection{AMD water chemistry}

Seasonal variations in $\mathrm{pH}$ and dissolved concentrations of $\mathrm{Fe}(\mathrm{II})$ and $\mathrm{S}$ were not significant at GB and FR sites. Representative distributions of aquatic physico-chemical parameters measured in February are shown in Fig. 1. The aqueous phase of the GB AMD contains $\sim 0.9 \mathrm{mM} \mathrm{Fe}$ (II) at the emergence point (GB1). Iron(II) was however completely removed from GB AMD waters after $15 \mathrm{~m}$ of downstream movement (Fig. 1b). Iron(II) removal from FR waters was less extensive due to different hydrological conditions [flow rate (50 and $136 \mathrm{~L} / \mathrm{min}$ at GB and FR, respectively (Senko et al., 2008); distance from source to stream junction (127 and $10 \mathrm{~m}$ at GB and FR, respectively)]. Dissolved $\mathrm{Fe}(\mathrm{II})$ was detected at all FR sampling points with an average concentration of $2.2 \pm 0.2 \mathrm{mM}$ (Fig. 1d). Average concentrations of dissolved $\mathrm{S}$ were higher at FR $(4.04 \pm 0.13 \mathrm{mM})$ than at GB $(1.19 \pm$

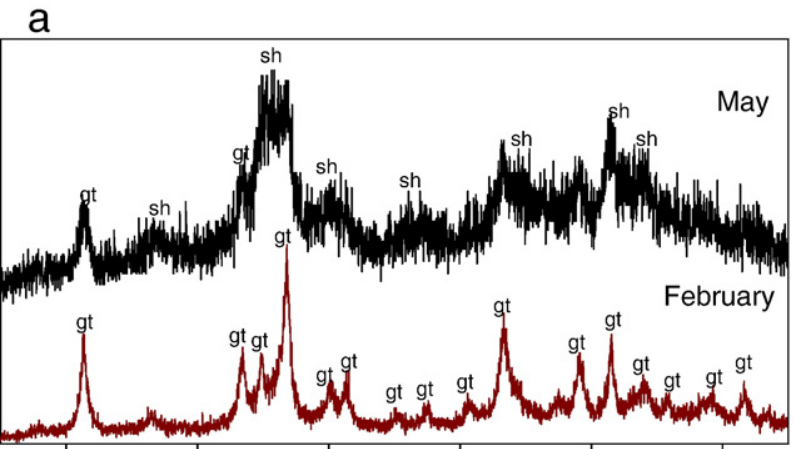

b

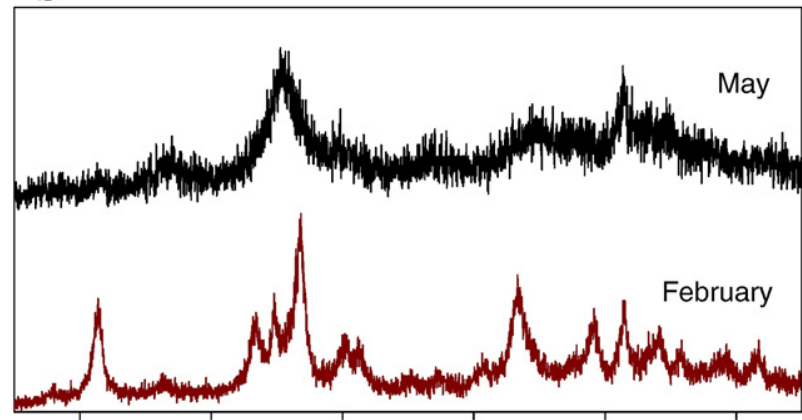

C

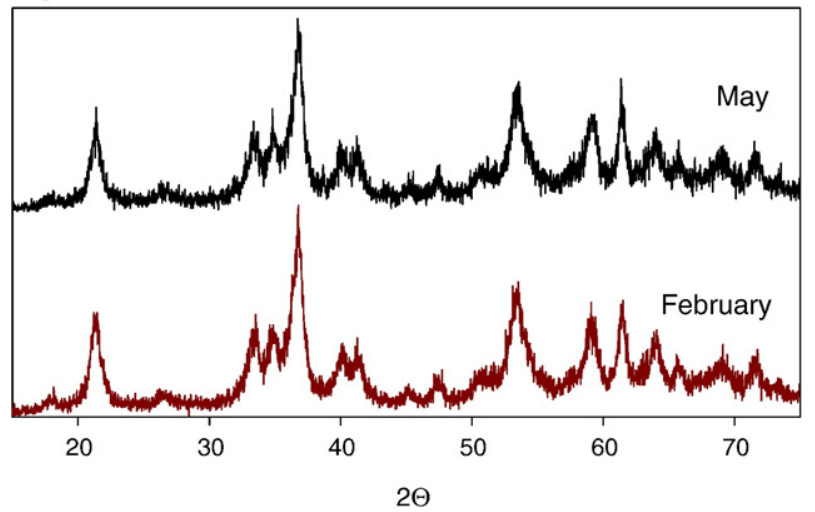

Fig. 2. X-ray powder diffraction patterns of the GB sediment samples collected in February and May: (a) GB1; (b) GB2; (c) GB3. gt-goethite, sh-schwertmannite. 
$0.04 \mathrm{mM}$ ) (Fig. 1b,d). Dissolved S concentration did not change significantly with distance from the source at both sites (Fig. 1b,d). The $\mathrm{pH}$ varied between 4.5-4.1 (source) and 3.7-3.9 downhill at both AMD sites (Fig. 1a,c). Low pH and high concentrations of dissolved S could be attributed not only to oxidation of sulfide minerals (Bigham et al., 1996; Malmstrom et al., 2006; Cravotta, 2008) but to post deposition mineralogical transformations in the AMD sediments.

\subsection{AMD mineralogy}

\subsection{1. $X R D$}

XRD analyses of the GB1-4 sediments collected in February downhill from the source to the point where water flows underground revealed that goethite was the dominant mineral. Goethite and quartz were present in GB 5-6 samples, i.e. downhill of water reemergence (Table 1). The mineralogy of the GB samples collected in May and July was significantly different for sites located in the source proximity $(0-2 \mathrm{~m})$. The summer samples of both GB1 and GB2 were composed primarily of schwertmannite, with some goethite in GB1 (Fig. 2a,b). No mineralogical changes were observed downhill of this location, and goethite remained the principal phase (ex. GB3, Fig. 2c). The presence of goethite together with schwertmannite, or goethite alone confirmed that schwertmannite was metastable with respect to goethite in these systems (Bigham et al., 1996; Gagliano et al., 2004; Murad and Rojik, 2005; Schwertmann and Carlson, 2005). Such changes in the initial precipitate mineralogy of the GB surface sediment might be due to seasonal variations in aqueous composition, water flow rate, and/or temperature. For instance, Kumpulainen et al. (2007) observed that schwertmannite formed in spring after snowmelt, but was partially transformed into goethite during warmer summer months. Drying led to precipitate cementation that limited S and $\mathrm{H}^{+}$diffusion, and prevented full conversion of schwertmannite to goethite (Kumpulainen et al., 2007). Cementation of the upper layers of mineral precipitates was common at both GB and FR sites.

The results of XRD analysis of the GB sediment depth series revealed no mineralogical changes at the GB3D site, where goethite was the principal mineral (Table 1). X-ray diffraction analysis of the GB1D depth series showed that the upper $0.3 \mathrm{~m}$ was composed primarily of schwertmannite with a trace amount of goethite (Fig. 3 , Table 1). The dominant phase in the two deepest samples of the GB1D column (0.6-1.1 m) was goethite (Fig. 3). The middle portion of the GB1D column (0.35-0.55 $\mathrm{m}$ ) represented a transition zone where the proportion of schwertmannite decreased, as goethite increased with depth. Similar transitions of schwertmannite to goethite with sediment depth were observed for the GB2 site. To summarize, the XRD study of the GB sediments demonstrated that mineralogical transformations occurred at both the surface and with depth in the AMD sediments.

The dominant mineral phase of samples FR1 through FR4 (February) was schwertmannite (Table 1). Along with schwertmannite, X-ray patterns of the FR4 displayed weak reflections of goethite (Table 1). The XRD data for the FR1 (July) sample showed that schwertmannite was the principal $\mathrm{Fe}$ (III) phase. It, however, also contained the traces of goethite. Comparison of the XRD data of the two FR samples collected at different times (February and July) showed that schwertmannite was the dominant phase, possibly due to slow mineralogical changes.

\subsubsection{SEM}

SEM analysis of GB1D (0-0.15 m, May) revealed that schwermannite formed spherical particles of 1-2 $\mu$ m diameter (Fig. 4a,b) that were associated in larger aggregates. The spherical particles of FR1 (February) schwertmannite had glassy, molten-like surfaces (Fig. 4c, d). Characteristic filamentous features (Cornell and Schwertmann, 2003) were not evident for any of the schwertmannite spherical particles in GB1D (0-0.15 m, May) and FR1 (February). The "pincushion" or filamentous morphology has been observed in loose precipitates but might be absent for schwertmannite from cemented GB and FR sediments (Bigham and Nordstrom, 2000).

SEM analysis also showed that GB1 (February) goethite particles exist as spheres (Fig. 4e,f) with morphology common to schwertmannite. Some of the goethite particles were hollow inside, while schwertmannite particles were firm and filled (Figs. 4a,b,e,f, and 5). The hollow goethite particles may form through dissolution of schwertmannite inside the spheres (Yu et al., 2003); however, further investigation is required. The spherical goethite morphology may be relict (pseudomorphic) from schwertmannite that was preserved during recrystallization. Others have noted that goethite can adopt the initial schwertmannite morphology and size (Sullivan and Bush, 2004; Jönsson et al., 2005; Schwertmann and Carlson, 2005). This

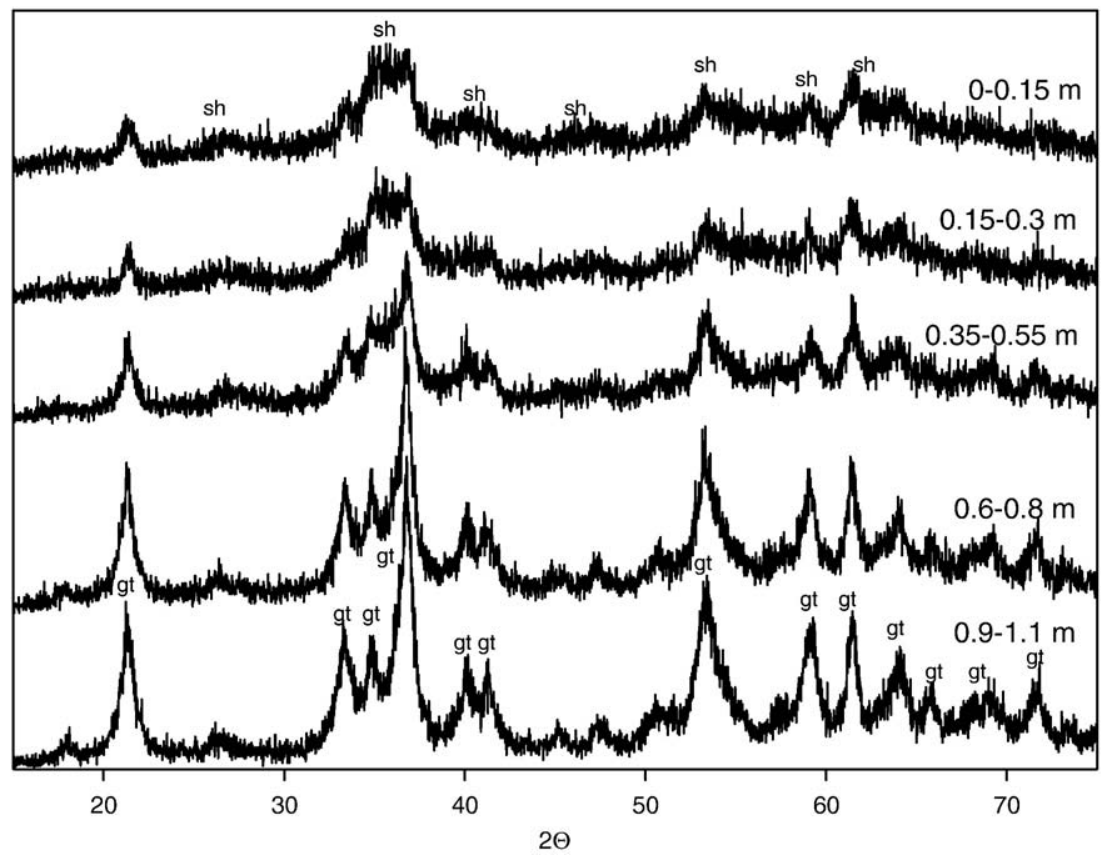

Fig. 3. X-ray powder diffraction patterns of the GB1D sediment samples collected at different depths. 

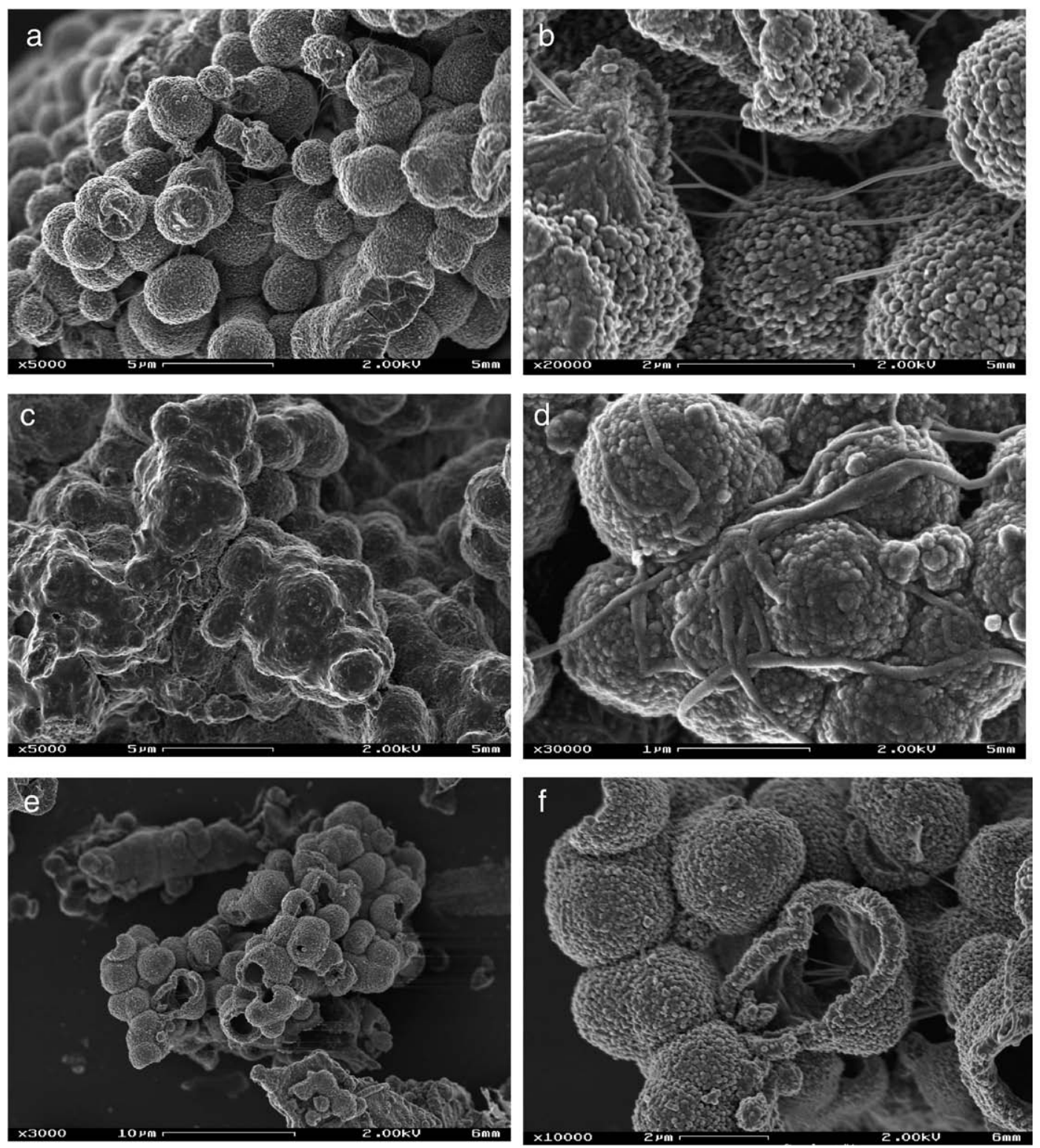

Fig. 4. Scanning electron microscopy images of (a) and (b) GB1D (0-0.15 m) collected in May; (c) FR1, (d) FR4, (e) and (f) GB1 collected in February.

relationship suggests a 1:1 transformation of schwertmannite aggregates into those of goethite (Schwertmann and Carlson, 2005).

Whole mount thin sectioned SEM analysis showed that the average $\mathrm{Fe} / \mathrm{S}$ ratios of GB1D (0-0.15 m, May), FR1 (February) and GB1 (February) were $8 \pm 3,9 \pm 2$ and $21 \pm 5$, respectively (Fig. 5 ). The Fe/S ratios for the GB1D (0-0.15 m, May) and FR1 (February) samples were within the range of that reported for schwertmannite (5.3-8, Bigham et al., 1990).

\subsubsection{FTIR}

All GB samples exhibited the characteristic in-plane $\left(\delta_{\mathrm{OH}}\right)$ and outof-plane $\left(\gamma_{\mathrm{OH}}\right)$ deformation modes of goethite at $\sim 900$ and $\sim 800 \mathrm{~cm}^{-1}$ (Fig. 6), respectively, consistent with the XRD analyses showing the importance of this phase. The $\mathrm{O}-\mathrm{H}$ stretching region (not shown) also displayed the important $3100 \mathrm{~cm}^{-1}$ band of goethite. The $\mathrm{O}-\mathrm{H}$ stretching region in the GB1D samples $(0-0.55 \mathrm{~m})$ revealed a secondary feature centered at $\sim 3400 \mathrm{~cm}^{-1}$ arising from schwertmannite, an observation consistent with the XRD analyses (Fig. 3). The infrared data are, as a whole, consistent with the XRD analyses and confirm the presence of both goethite and schwertmannite in the sediments.

The spectra of the sediment samples collected as a function of depth (GB1D sediments) and distance from the AMD source (GB1, GB3, GB5) were used to generate an asynchronous 2D correlation map to identify the important sulfate vibrational modes. The resulting map (Fig. 7c) reveals peaks at $1215,1135,1088,1065,1010$ and $985 \mathrm{~cm}^{-1}$ resulting for symmetric and asymmetric $\mathrm{S}-\mathrm{O}$ stretching vibrations of sulfate molecules. These modes, which are identified for sediment sample GB1D (0.35-0.55 m) (Fig. 7b) are comparable to those of the pure component spectra for three predominant mineral-bound sulfate geometries (Fig. 7a) that were resolved in another study from our group (unpublished). The 1215, 1135 and $985 \mathrm{~cm}^{-1}$ bands correspond to the $C_{2 v}$ geometry of sulfate [that is, a sulfate bidentate complex (Peak et al., 1999) in the schwertmannite structure and/or at the Fe(III) oxide surface, and/or strongly hydrogen-bonded complexes (Majzlan and Myneni, 2005)]. The 1135, 1065 and $985 \mathrm{~cm}^{-1}$ bands arise, on the other hand, from sulfate surface complexes of $\mathrm{C}_{3 \mathrm{v}}$ symmetry [a monodentate sulfate complex (Peak et al., 1999) at the Fe(III) oxide surface]. The presence of the both sets of bands therefore denote the existence of both types of surface complexes in the AMD Fe(III) precipitates. A third complex that is hydrogen-bonded or physisorbed ( $T_{d}$, Peak et al., 1999; Jönsson et al., 2005) is also present.

The GB1 sediment exhibits the strongest degree of $v_{3}$ splitting and therefore the strongest proportion of bidentate sulfate complexes of 
a

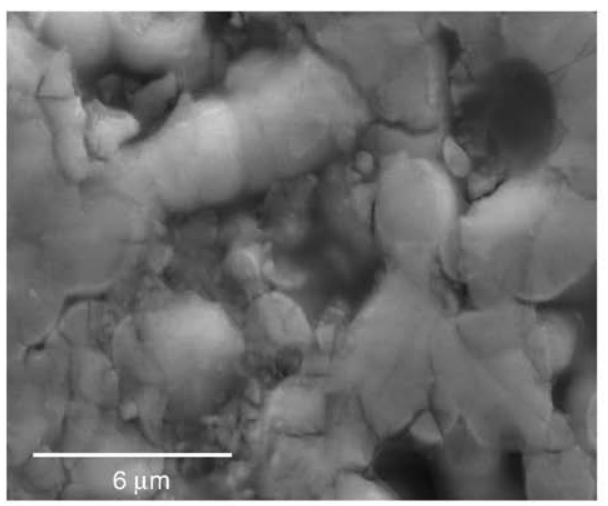

b

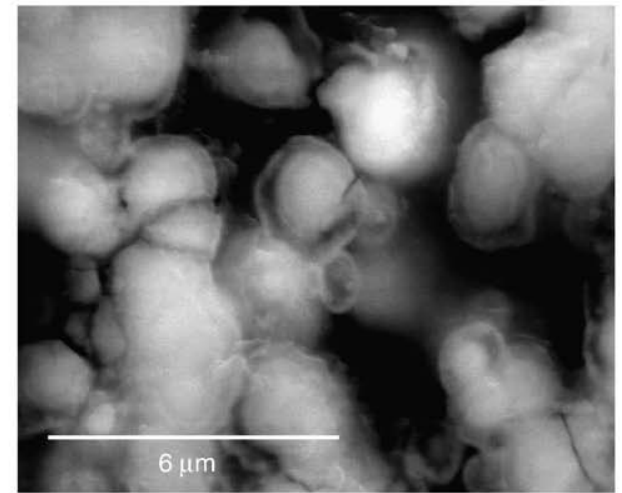

C

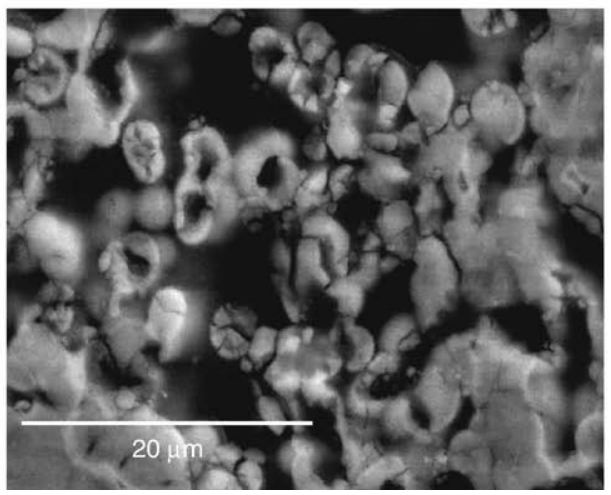

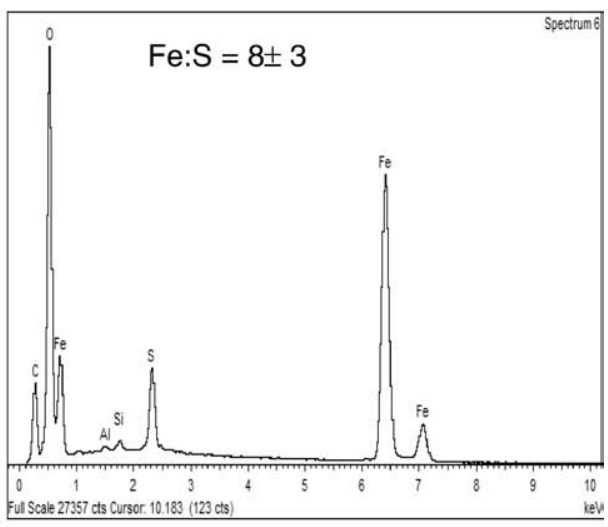
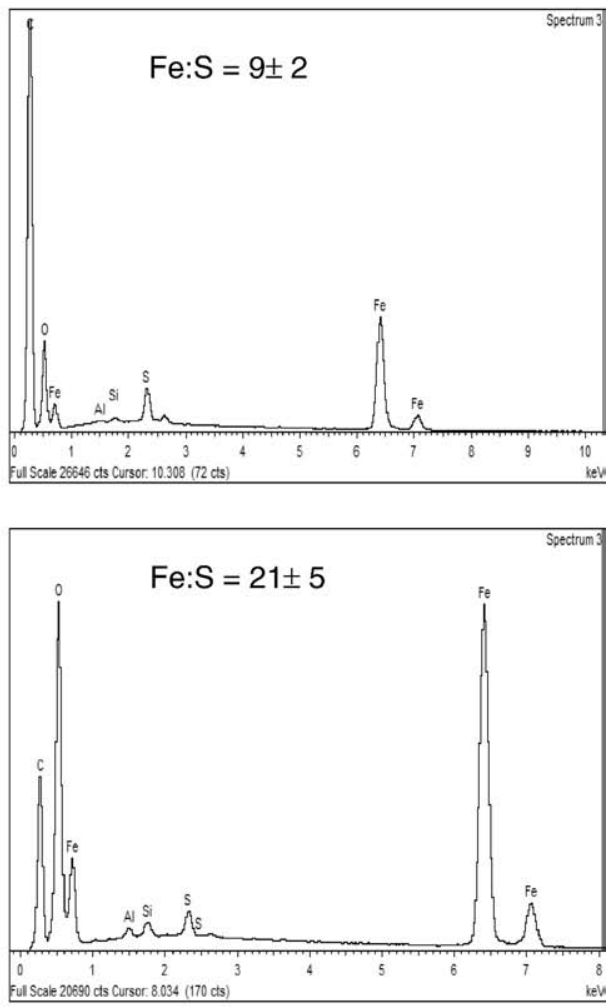

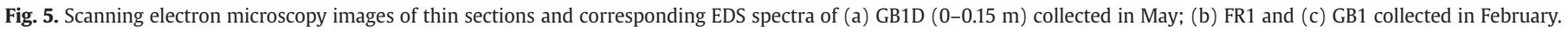

$\mathrm{C}_{2 \mathrm{~V}}$ symmetry (Fig. 6a). A decrease in $v_{3}$ splitting occurs with distance from the AMD source, implying conversion of bidentate $C_{2 V}$ complexes to monodentate $C_{3 v}$-type complexes on the goethite surface. Similar to GB surface samples (Fig. 6a), the speciation of sulfate as a function of sediment depth also exhibits a decrease in the intensity of the high-energy $\nu_{3}$ band, denoting a change from the $C_{2 V}$ symmetry of the schwertmannite-bound sulfate complex at the surface of GB1D to a $C_{3 V}$ symmetry for sulfate bound to the surface of goethite particles present in the deeper sediments (Fig. 6b). Going from the surface [GB1D $(0-0.15 \mathrm{~m})$ ] to deeper sediments [GB1D $(0.35-$ $0.55 \mathrm{~m})$ and GB1D (0.9-1.1 m], also increases the relative importance of goethite bands (e.g. the in-plane and out-of-plane) relative to the area of the $\mathrm{S}-\mathrm{O}$ stretching area, a result that is consistent with the EDS spectra of Fig. 5 in terms of the Fe/S ratios and XRD results (Fig. 3).

\subsection{Chemical extractions of the AMD sediments}

The amount of oxalate extracted Fe from the GB (February) surface samples decreased from $94 \%$ to $2 \%$ of $\mathrm{Fe}_{\mathrm{HCl}}$ downhill from the emergence point due to an increase in goethite crystallinity
(Table 1). The concentration of $\mathrm{Fe}_{\mathrm{HCl}}$ decreased along the profile as well, through dilution of the Fe(III) phases with quartz (Table 1). Similarly, the S content decreased with distance from the source (Table 1). Up to 51-97\% of $\mathrm{S}_{\mathrm{HCl}}$ was extracted at $\mathrm{pH} 10$ from the GB samples indicating that most of the $\mathrm{S}$ was associated with the goethite surface. Overall, the poorly-crystalline, S-rich goethite was located near the GB source; its crystallinity increased downstream while S content decreased.

The concentrations of $\mathrm{S}_{\mathrm{Ox}}$ and $\mathrm{S}_{\mathrm{HCl}}$ in the schwertmannitecontaining GB surface samples [GB1D(0-0.15 m, May), GB2D(0$0.15 \mathrm{~m}$, May) and GB1 (July)] were close to or slightly higher than those of the goethite-containing GB1 (February) and GB2 (February) samples, respectively, while $\mathrm{S}_{\mathrm{pH} 10}$ was $0.23-0.28 \mathrm{mmol} / \mathrm{g}$ lower (Table 1). These results implied that there was little release of structural S during the schwertmannite transformation, and that most of the $S$ became surface-complexed. Concentrations of extractable $S$ from GB schwertmannite and goethite were in good agreement with the laboratory study of Schwertmann and Carlson (2005), where the conversion of schwertmannite was shown to result in the adsorption of considerable amounts of sulfate to the goethite surface. These 
a

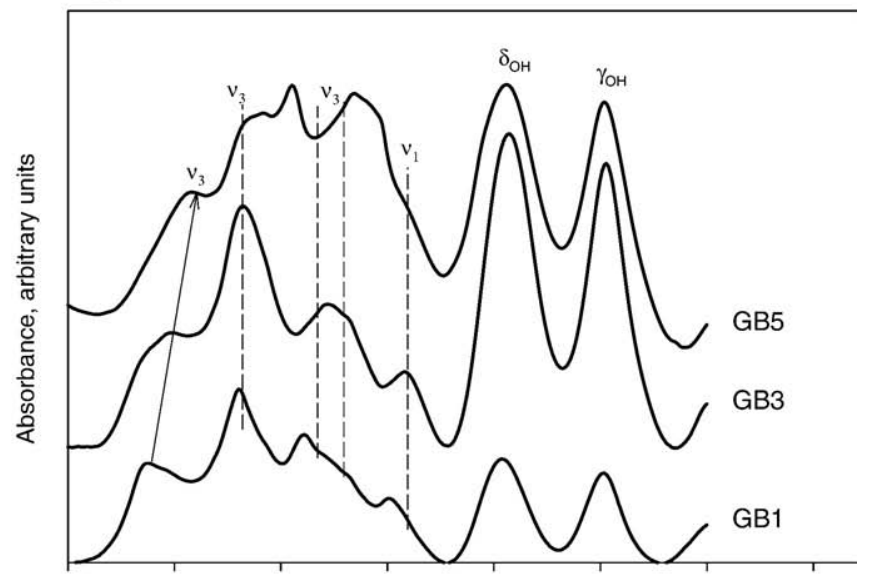

b

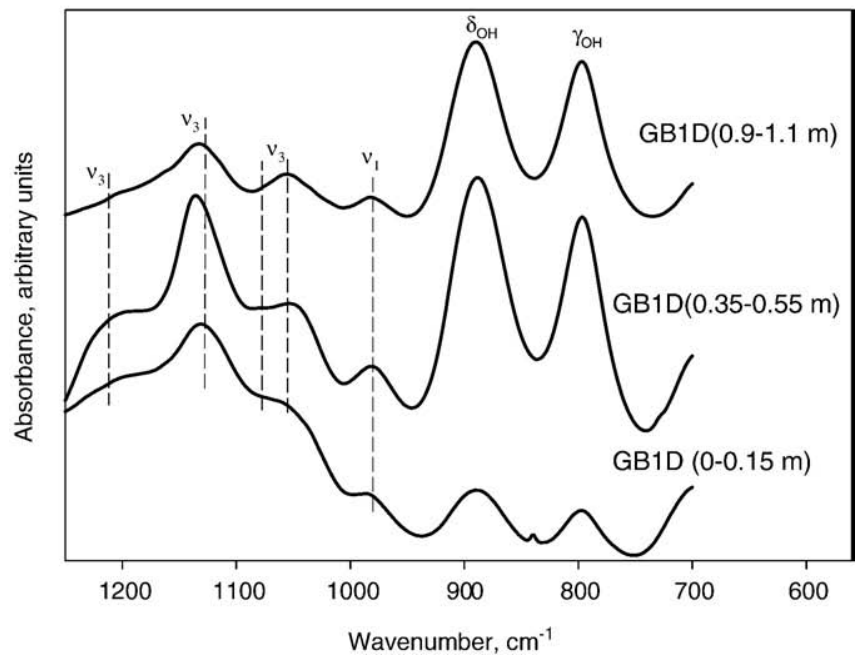

Fig. 6. FTIR spectra of (a) GB surface samples collected in February and (b) GB1D sediment samples collected at different depths in May.

authors hypothesized that sulfate adsorption caused the spherical morphology of goethite.

In contrast to $\mathrm{GB}$, the concentration of the oxalate-extractable Fe in the FR samples averaged $\sim 6.7 \mathrm{mmol} / \mathrm{g}$ and did not change significantly with distance from the source or sampling time [FR1 (February and July)]. The $\mathrm{Fe}_{\mathrm{ox}} / \mathrm{Fe}_{\mathrm{HCl}}$ ratio ranged from $85 \%$ to $94 \%$ because schwertmannite was the principal Fe(III) phase (Table 1). The average chemical formula of schwertmannite obtained from the oxalate extraction data was $\mathrm{Fe}_{8} \mathrm{O}_{8}(\mathrm{OH})_{5.56}\left(\mathrm{SO}_{4}\right)_{1.22}$.

Vertical profiles at the GB1 (May) and GB2 (May) sites showed similar Fe and $\mathrm{S}$ depth trends (Table 1). The oxalate extracted Fe decreased with depth, while $\mathrm{Fe}_{\mathrm{HCl}}$ slightly increased, indicating an increase in goethite crystallinity. Similar to the GB (February) surface samples, the increase in crystallinity was accompanied by a drop in $\mathrm{S}$ content. The vertical distribution therefore showed that mineralogical changes from schwertmannite to goethite at GB1 (May) and GB2 (May) sites were accompanied by an increase in goethite crystallinity concomitant with the depletion of sulfate. In the sediment depth samples, $67-100 \%$ of $\mathrm{S}_{\mathrm{HCl}}$ was extracted at $\mathrm{pH} 10$, indicating that the majority of S was surface bound to goethite and schwertmannite. The average chemical formula of schwertmannite obtained from the oxalate extraction data of GB1 and GB2 depth samples was similar to the one found for the FR schwertmannite.

To summarize, the results of mineralogical analysis showed that schwertmannite transformation occurred at GB site. Little release of sulfate occurred into aqueous solution during the transformations and the initially formed goethite was poorly-crystallized and rich in surface bound sulfate. The goethite had spherical morphology due to preservation of schwertmannite structure by adsorbed sulfate. The poorly-crystallized goethite was subject to further crystallization accompanied by $\mathrm{S}$ desorption to the aqueous phase. Changes in surface speciation preceded sulfate desorption, with a conversion from $C_{2 v}$ to $C_{3 v}$ symmetry. Further experimental study is however necessary to evaluate the effect of the mineral transformation on water chemistry.

\subsection{Sediment incubation}

Incubation experiments were performed to study the influence of schwertmannite transformation on AMD waters that differ in $\mathrm{pH}$ and composition (GB4w and GB6w, Table S2). The $\mathrm{pH}$ values in all suspensions gradually decreased during incubation to $\sim 2.2$ (GB1 sediments) and $\sim 1.9$ (FR1 sediments) (Fig. 8). Unlike the suspensions with GB4 water, for which no shift in the initial $\mathrm{pH}$ value was observed, mixing GB1 and FR1 sediments with GB6 water (initial $\mathrm{pH}=5.15$, Table $\mathrm{S} 2$ ) resulted in an immediate $\mathrm{pH}$ drop from 5.15 to 2.9. When the aqueous phase was replaced in the GB1s_GB6w and FR1_GB6w suspensions after approximately $100 \mathrm{~d}$, the pH value still dropped to 2.9 within one day (Fig. 8, note arrows). The $\mathrm{pH}$ decrease was due to schwertmannite acidity which made it a significant proton source (Bigham et al., 1996; Gagliano et al., 2004; Murad and Rojik, 2005; Schwertmann and Carlson, 2005). Based on the average schwertmannite composition of $\mathrm{Fe}_{8} \mathrm{O}_{8}(\mathrm{OH})_{5.56}\left(\mathrm{SO}_{4}\right)_{1.22}$ determined by oxalate extraction (Table 1 ), around $0.3 \mathrm{~mol} \mathrm{H}^{+}$could be released per mole of $\mathrm{Fe}^{3+}$ upon hydrolysis to goethite, a result that is in agreement with published data $\left[0.26-0.40 \mathrm{~mol} \mathrm{H}^{+}\right.$;(Bigham et al.,

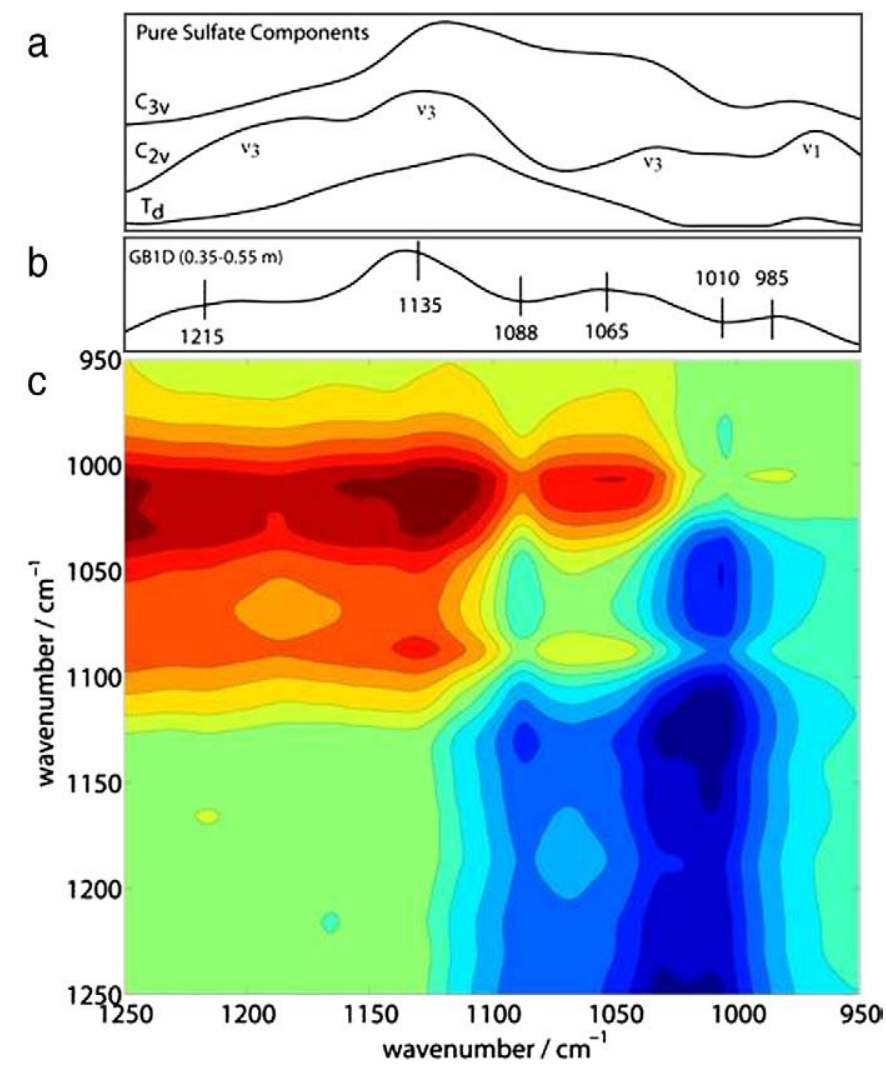

Fig. 7. FTIR spectra of (a) pure sulfate components resolved for synthetic schwertmannite (unpublished), (b) GB1D $(0.35-0.55 \mathrm{~m})$ and (c) asynchronous 2D correlation map built from FTIR spectra shown in Fig. 6. 

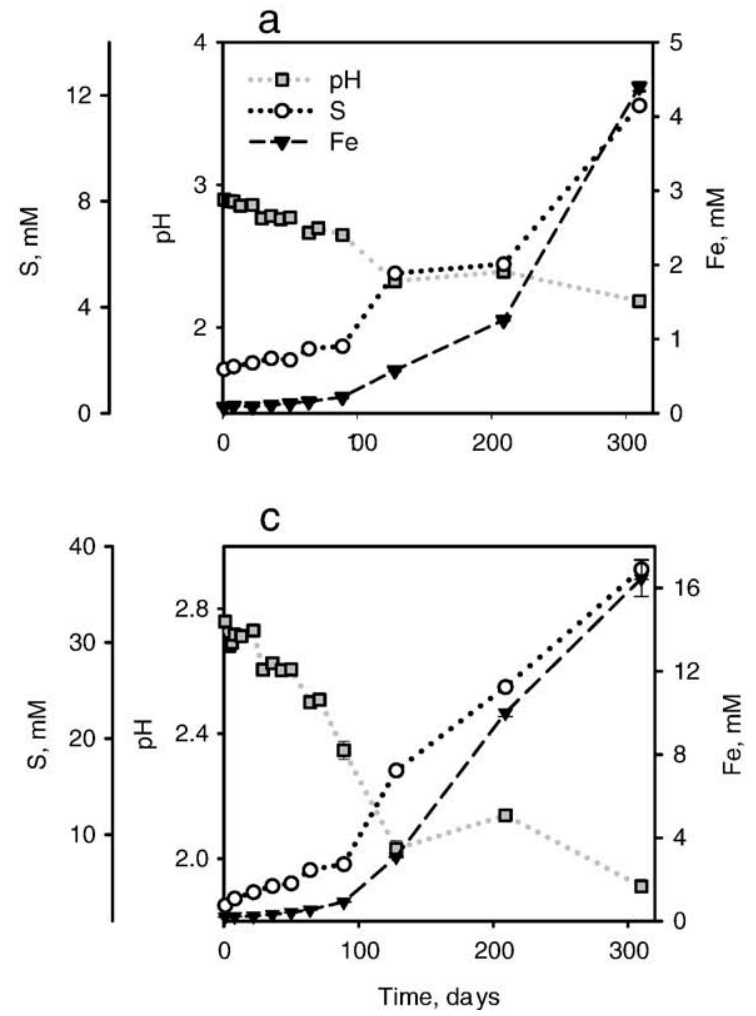
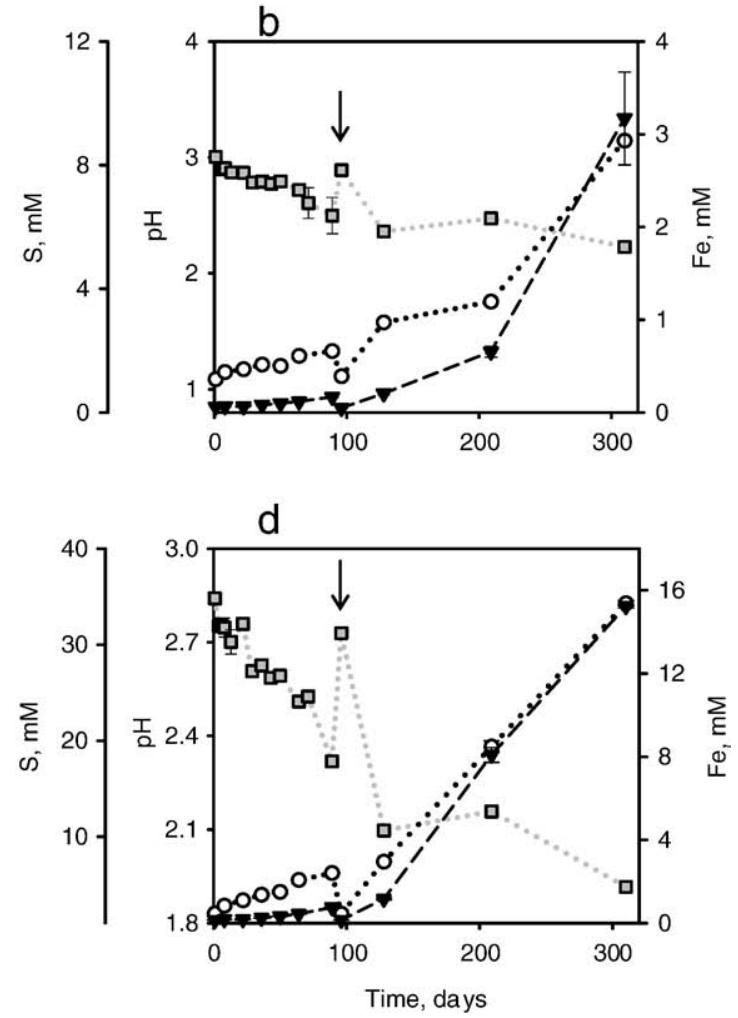

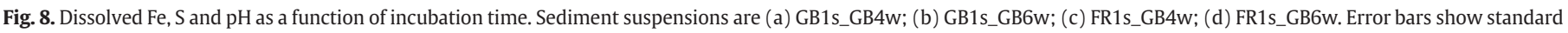
deviation (two replicates). Arrows denote time when aqueous phase was replaced.

1996; Peine et al., 2000; Kawano and Tomita, 2001)]. The decrease in pH was accompanied by an increase in dissolved Fe and S (Fig. 8).

At the end of incubation, the Fe and $\mathrm{S}$ concentrations were lower in GB1 suspensions $[11.61 \pm 0.12 \mathrm{mM}$ and $10.76 \pm 0.78 \mathrm{mM} \mathrm{S} ; 4.40 \pm$ $0.06 \mathrm{mM}$ and $3.85 \pm 0.49 \mathrm{mM}$ Fe in the GB1s_GB4w and GB1s_GB6w, respectively] than in the FR1 suspensions [ $37.61 \pm 1.05 \mathrm{mM}$ and $40.51 \pm$ $0.29 \mathrm{mM}$; ; $16.43 \pm 0.87 \mathrm{mM}$ and $15.98 \pm 0.08 \mathrm{mM}$ Fe in FR1s_GB4w and FR1s_GB6w, respectively]. Regardless of differences in the initial composition of GB4w and GB6w (Table S2), the final concentrations of Fe and $\mathrm{S}$ were of comparable order of magnitude in suspensions of the same sediment (e.g., GB1s_GB4w and GB1s_GB6w). Calculation of saturation indices revealed that all sediment suspensions were undersaturated with respect to schwertmannite and supersaturated with respect to goethite (Fig. 9). Thus, dissolution and/or transformation of schwertmannite controlled the chemical composition of the aqueous phase (i.e., $\mathrm{pH}$ and $\mathrm{S}$ content).

Mineralogical changes were significant in the GB1 and FR1 incubations, where XRD analysis revealed that goethite was the principal $\mathrm{Fe}(\mathrm{III})$ mineral at experiment termination (Fig. S3). The concentration of $\mathrm{Fe}_{\mathrm{ox}}$ began to decrease after approximately $128 \mathrm{~d}$ coincident with goethite crystallization (Fig. S4). We unexpectedly found that the schwertmannite to goethite transformation occurred under laboratory conditions in FR1. This observation contrasted with the XRD analysis of the FR sediments (May and February) that revealed no significant goethite formation in FR sediments (Table 1). This difference might be explained by different field and laboratory temperature and chemical conditions, and the influence of AMD advection over and within the $\mathrm{Fe}(\mathrm{III})$ deposits. It is possible that the rate of schwertmannite precipitation and accretion was faster than its transformation into goethite at the FR site. Further laboratory and field studies are required to resolve this interesting disparity.

The laboratory incubation experiments demonstrated that schwertmannite dissolution and/or transformation controlled AMD water chemistry under no-flow, batch conditions. AMD properties (acidity, dissolved S) are therefore regulated by two important sources: (i) primary sulfide minerals (pyrite, pyrrhotite) and (ii) secondary metastable $\mathrm{Fe}(\mathrm{III})$ phases formed after $\mathrm{Fe}^{2+}$ oxidation.

\subsection{Environmental implications}

Our results demonstrate an important relationship between mineralogical transformations and the water composition of AMD. Conversion of schwertmannite to goethite leads to decrease in $\mathrm{pH}$ and increase in the dissolved concentration of sulfate (Fig. 10) as found in laboratory incubations of AMD sediments [this work; (Schwertmann

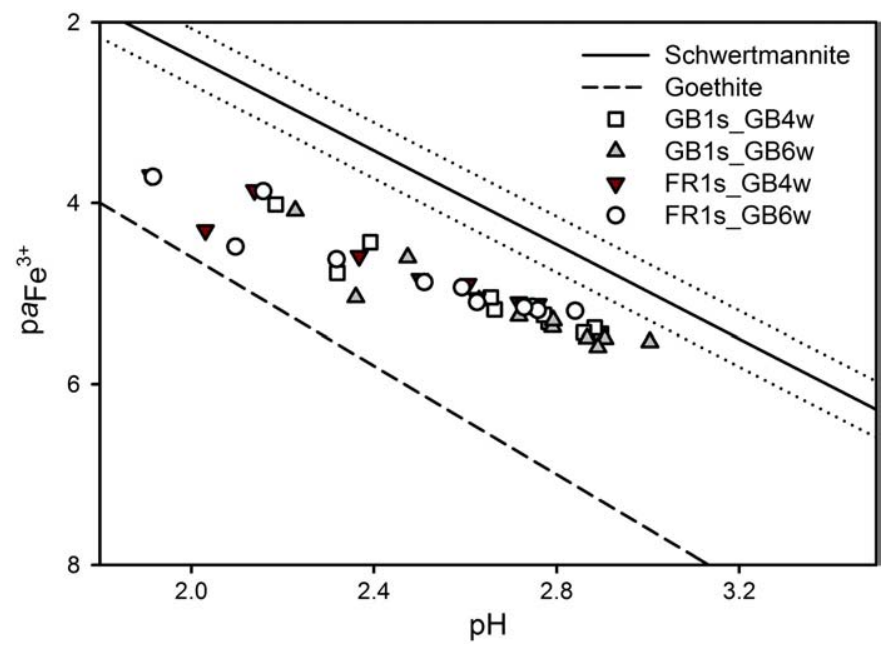

Fig. 9. Plots of $\mathrm{p} a_{\mathrm{Fe} 3+} \mathrm{vs} \mathrm{pH}$ for the sediment suspensions. The solubility lines of schwertmannite and goethite were calculated by Eqs. (4) and (5) for pa $a_{\mathrm{SO} 42-}=2.84$. Dotted lines are boundaries of the solubility window of schwertmannite. Solubility products of schwertmannite and goethite were taken from Bigham et al., 1996. 


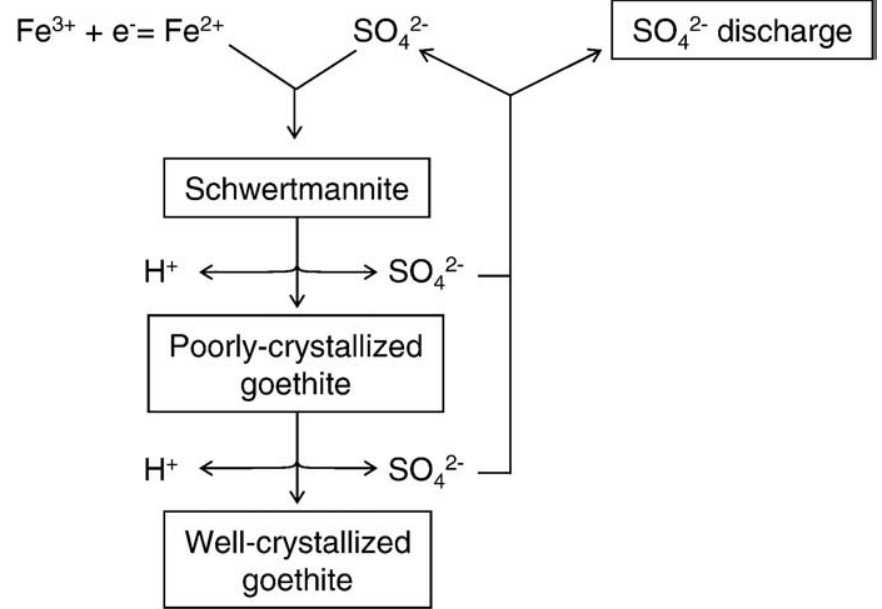

Fig. 10. Schematic of schwertmannite conversion to well-crystallized goethite based on results of mineralogical analysis and laboratory incubation of AMD sediments.

et al., 1995; Bigham et al., 1996; Jönsson et al., 2005; Knorr and Blodau, 2007)] and in field conditions (Kumpulainen et al., 2007). At GB and FR sites, the noted $\mathrm{pH}$ decrease from 4.1-4.5 (source) to 3.7-3.9 downhill (Fig. 1a,c) could, therefore, be explained by Fe(II) oxidation to Fe(III) with subsequent precipitation (Senko et al., 2008) and by conversion of secondary metastable Fe(III) phases (e.g., schwertmannite). However, the dissolved S concentration in GB and FR systems does not change significantly between sampling points (GB1-6, FR1-4) or sampling time (February and May) (Fig. 1b,d). Average concentrations of dissolved $\mathrm{S}$ were higher at FR $(4.04 \pm 0.13 \mathrm{mM})$ than at GB $(1.19 \pm$ $0.04 \mathrm{mM})$. Such uniform $S$ concentrations over time and with distance from the source may be explained by a low (as compared to flow) rate of $\mathrm{S}$ release from $\mathrm{Fe}(\mathrm{III})$ solid phases and/or by reprecipitation of the released S in schwertmannite (Fig. 10).

Other field measurements [such as, schwertmannite precipitation/ accretion rate and its transformation into goethite, rate of sulfate release from sediments, pore water composition] are needed to fully interpret factors controlling AMD water and sediment composition.

\section{Acknowledgements}

We thank John Senko and Melanie Lucas (Pennsylvania State University) for providing us with sediment and water samples. We are grateful to Tom Resch (PNNL) for the thin sections preparation. We thank Ravi Kukkadapu (PNNL) for the valuable discussions on the interpretation of AMD mineralogy data. XRD, SEM and FTIR analysis were performed in the Environmental Molecular Sciences Laboratory (EMSL) that is managed and supported by OBER-ERSD. PNNL is operated for the DOE by Battelle. This work was partially supported by the National Science Foundation under Grant No. CHE-0431328 and the U.S. Department of Energy, Biological and Environmental Research (BER).

\section{Appendix A. Supplementary data}

Supplementary data associated with this article can be found, in the online version, at doi:10.1016/j.chemgeo.2009.01.017.

\section{References}

Acero, P., Ayora, C., Torrento, C., Nieto, J.M., 2006. The behavior of trace elements during schwertmannite precipitation and subsequent transformation into goethite and jarosite. Geochimica et Cosmochimica Acta 70 (16), 4130-4139.

Bigham, J.M., Nordstrom, D.K., 2000. Iron and aluminum hydroxysulfates from acid sulfate waters. In: Alpers, C.N., Jambor, J.L., Nordstrom, D.K. (Eds.), Sulfate minerals, crystallography, geochemistry and environmental significance. Reviews in mineralogy and geochemistry. Mineralogical Society of America, Washington, D.C., pp. 351-403.
Bigham, J.M., Schwertmann, U., Carlson, L., Murad, E., 1990. A poorly crystallized oxyhydroxysulfate of iron formed by bacterial oxidation of $\mathrm{Fe}(\mathrm{II})$ in acid-mine waters. Geochimica et Cosmochimica Acta 54 (10), 2743-2758.

Bigham, J.M., Schwertmann, U., Traina, S.J., Winland, R.L., Wolf, M., 1996. Schwertmannite and the chemical modeling of iron in acid sulfate waters. Geochimica et Cosmochimica Acta 60 (12), 2111-2121.

Boily, J.-F., Ilton, E.S., 2008. An independent confirmation of the correlation of Uf4 primar peaks and satellite structures of UVI, UV and UIV in mixed valence uranium oxides by two-dimensional correlation spectroscopy. Surface Science 602, 3637-3646.

Burton, E.D, Bush, R.T., Sullivan, L.A., Mitchell, D.R.G., 2008. Schwertmannite transformation to goethite via the $\mathrm{Fe}(\mathrm{II})$ pathway: reaction rates and implications for iron-sulfide formation. Geochimica et Cosmochimica Acta 72 (18), 4551-4564.

Carlson, L., Bigham, J.M., Schwertmann, U., Kyek, A., Wagner, F., 2002. Scavenging of As from acid mine drainage by schwertmannite and ferrihydrite: a comparison with synthetic analogues. Environmental Science and Technology 36 (8), 1712-1719.

Cornell, R.M., Schwertmann, U., 2003. The iron oxides: structure, properties, reactions, occurrences and uses. Wiley-VCH, New York. 664 pp.

Cravotta, C.A., 2008. Dissolved metals and associated constituents in abandoned coalmine discharges, Pennsylvania, USA. Part 2: geochemical controls on constituent concentrations. Applied Geochemistry 23 (2), 203-226.

Dold, B., Fontbote, L., 2001. Element cycling and secondary mineralogy in porphyry copper tailings as a function of climate, primary mineralogy, and mineral processing. Journal of Geochemical Exploration 74 (1-3), 3-55.

Espana, J.S., Pamo, E.L., Pastor, E.S., Andres, J.R., Rubi, J.A.M., 2006. The removal of dissolved metals by hydroxysulphate precipitates during oxidation and neutralization of acid mine waters, Iberian Pyrite Belt. Aquatic Geochemistry 12 (3), 269-298.

Fukushi, K., Sasaki, M., Sato, T., Yanase, N., Amano, H., Ikeda, H., 2003. A natural attenuation of arsenic in drainage from an abandoned arsenic mine dump. Applied Geochemistry 18 (8), 1267-1278.

Gagliano, W.B., Brill, M.R., Bigham, J.M., Jones, F.S., Traina, S.J., 2004. Chemistry and mineralogy of ochreous sediments in a constructed mine drainage wetland. Geochimica et Cosmochimica Acta 68 (9), 2119-2128.

Hochella, M.F., Moore, J.N., Golla, U., Putnis, A., 1999. A TEM study of samples from acid mine drainage systems: metal-mineral association with implications for transport. Geochimica et Cosmochimica Acta 63 (19-20), 3395-3406.

Jönsson, J., Persson, P., Sjoberg. S., Lovgren, L., 2005. Schwertmannite precipitated from acid mine drainage: phase transformation, sulphate release and surface properties. Applied Geochemistry 20 (1), 179-191.

Kawano, M., Tomita, K., 2001. Geochemical modeling of bacterially induced mineralization of schwertmannite and jarosite in sulfuric acid spring water. American Mineralogist 86 (10), 1156-1165.

Knorr, K.H., Blodau, C., 2007. Controls on schwertmannite transformation rates and products. Applied Geochemistry 22 (9), 2006-2015.

Kumpulainen, S., Carlson, L., Raisanen, M.L., 2007. Seasonal variations of ochreous precipitates in mine effluents in Finland. Applied Geochemistry 22 (4), 760-777.

Majzlan, J., Myneni, S.C.B., 2005. Speciation of iron and sulfate in acid waters: aqueous clusters to mineral precipitates. Environmental Science and Technology 39 (1), 188-194.

Malmstrom, M.E., Gleisner, M., Herbert, R.B., 2006. Element discharge from pyritic mine tailings at limited oxygen availability in column experiments. Applied Geochemistry 21 (1), 184-202.

Murad, E., Rojik, P., 2005. Iron mineralogy of mine-drainage precipitates as environmental indicators: review of current concepts and a case study from the Sokolov Basin, Czech Republic. Clay Minerals 40 (4), 427-440.

Noda, I., Ozaki, Y., 2004. Two-dimensional correlation spectroscopy-applications in vibrational and optical spectroscopy. John Wiley and Sons, New York.

Parkhurst, D.L., Appelo, C.A.J., 1999. User's guide to PHREEOC (version 2) - a computer program for speciation, batch-reaction, one-dimensional transport, and inverse modeling. U.S. Geological Survey Water-Resources Investigations Report 99-4259.

Peak, D., Ford, R.G., Sparks, D.L., 1999. An in situ ATR-FTIR investigation of sulfate bonding mechanisms on goethite. Journal of Colloid and Interface Science 218 (1), 289-299.

Peine, A., Tritschler, A., Kusel, K., Peiffer, S., 2000. Electron flow in an iron-rich acidic sediment - evidence for an acidity-driven iron cycle. Limnology and Oceanography 45 (5), 1077-1087.

Regenspurg, S., Peiffer, S., 2005. Arsenate and chromate incorporation in schwertmannite. Applied Geochemistry 20 (6), 1226-1239.

Regenspurg, S., Brand, A., Peiffer, S., 2004. Formation and stability of schwertmannite in acidic mining lakes. Geochimica et Cosmochimica Acta 68 (6), 1185-1197.

Schwertmann, U., Carlson, L., 2005. The pH-dependent transformation of schwertmannite to goethite at $25^{\circ} \mathrm{C}$. Clay Minerals 40 (1), 63-66.

Schwertmann, U., Bigham, J.M., Murad, E., 1995. The first occurrence of schwertmannite in a natural stream environment. European Journal of Mineralogy 7 (3), 547-552.

Senko, J.M., Wanjugi, P., Lucas, M., Bruns, M.A., Burgos, W.D., 2008. Characterization of $\mathrm{Fe}(\mathrm{II})$ oxidizing bacterial activities and communities at two acidic Appalachian coal mine drainage-impacted sites. The ISME Journal: Multidisciplinary. Journal of Microbial Ecology 2 (11), 1134-1145.

Sullivan, L.A., Bush, R.T., 2004. Iron precipitate accumulations associated with waterways in drained coastal acid sulfate landscapes of eastern Australia. Marine and Freshwater Research 55 (7), 727-736.

Yu, S.H., Colfen, H., Antonietti, M., 2003. Polymer-controlled morphosynthesis and mineralization of metal carbonate superstructures. Journal of Physical Chemistry B 107 (30), 7396-7405. 